\title{
Feeding habits of the congeneric species Stellifer rastrifer and Stellifer brasiliensis (Acanthopterygii: Sciaenidae) co-occurring in the coast of the state of Santa Catarina, Brazil
}

\author{
Sabinson, LM. ${ }^{a *}$, Rodrigues-Filho, JL. ${ }^{a}$, Peret, AC. ${ }^{a}$, Branco, JO. ${ }^{b}$ and Verani, JR. ${ }^{a}$ \\ ${ }^{a}$ Laboratório de Ictiologia e Dinâmica de Populações, Departamento de Hidrobiologia, Universidade Federal de \\ São Carlos - UFSCar, Rodovia Washington Luís, km 235, CEP 13565-905, São Carlos, SP, Brazil \\ bUniversidade do Vale do Itajaí - UNIVALI, Rua Uruguai, 458, setor D4, sala 203, CEP 88302-202, Itajaí, SC, Brazil \\ *e-mail: liasabinson@gmail.com
}

Received: September 9, 2013 - Accepted: January 6, 2014 - Distributed: May 31, 2015

(With 4 figures)

\begin{abstract}
The objective of the present study was to investigate the feeding habits allowing the occurrence of the congeneric species Stellifer rastrifer and Stellifer brasiensis, collected on a seasonal basis, in the operating area of the artisanal seabob-shrimp trawl fishery in Porto Belo, an important fishing area on the southern Brazilian coast. Fish were collected seasonally from November 2009 to August 2010, in isobaths of 10, 20 and 30m. Of the 450 stomachs analyzed, 194 belongd to Stellifer rastrifer and 242 to Stellifer brasiliensis. From the totality of analyzed stomachs $33.49 \%$ were empty and $66.52 \%$ had some content. Crustacea were the predominant food category in the diet of S. rastrifer and S. brasiliensis, and the shrimp Acetes americanus was the most frequent crustacean in stomachs of both studied species. The overlapping in the diet of the species was high, however when analyzing the overlap in each season it was found that it occurred only during spring and winter. Although the most important items in the diet of these species are the same, the intake of each alternates in time, suggesting a difference in predation pressure, which leads to less direct competition in a given time.
\end{abstract}

Keywords: competition, fish diet, feeding overlap, shrimp fisheries, Stellifer.

\section{Hábitos alimentares das espécies congêneres Stellifer rastrifer e Stellifer brasiliensis (Acanthopterygii: Sciaenidae) co-ocorrendo na costa do estado de Santa Catarina, Brasil}

\begin{abstract}
Resumo
O objetivo do presente estudo foi investigar os hábitos alimentares que possibilitam a ocorrência das espécies congêneres Stellifer rastrifer e Stellifer brasiensis, coletados sazonalmente, na área operacional da pesca artesanal do camarão setebarbas, em Porto Belo, uma área de pesca importante na costa sul do Brasil. Os peixes foram coletados sazonalmente de novembro de 2009 a agosto de 2010, em isóbatas de 10, 20 e 30m. Dos 450 estômagos analisadas, 194 eram de S. rastrifer e 242 de $S$. brasiliensis. Da totalidade dos estômagos analisados 33,49\% estavam vazios enquanto $66,52 \%$ tinham algum conteúdo. Crustacea foi a categoria de alimento predominante na dieta, e o camarão Acetes americanus foi o crustáceo mais freqüente nos estômagos de ambas as espécies. A sobreposição na dieta foi alta, porém a cada estação do ano, verificou-se que a sobreposição ocorreu apenas durante a primavera e o inverno. Embora os itens mais importantes na dieta destas espécies sejam os mesmos, o consumo de cada um é alternado no tempo, o que sugere uma diferença na pressão de predação, levando a uma menor competição direta em um determinado momento.
\end{abstract}

Palavras-chave: competição, dieta, sobreposição alimentar, pesca camaroeira, Stellifer.

\section{Introduction}

Bycatch is defined as the catch of individuals by a fishing gear which is targeting another species. It is a well known and under exploited resource in many countries while it may be overvalued in others (Mathews and Samuel, 1991). As shrimp fisheries are responsible for the largest bycatch among all fishing gears in the world (Keunecke et al.,

2007), a large amount of the catch - composed mainly by immature organisms - is rejected on board and returned to the sea since it has no commercial value, (Vazzoler, 1962), however the study of the discarded species was made necessary, as many of them might have commercial value in the near future. 
According to Sheridan et al. (1984), Sciaenidae, Haemulidae, Sparidae, Synodontidae, Serranidae and Paralichthyidae are the families of demersal fish commonly found in the same areas of occurrence of Penaeidae shrimps, such as the seabob-shrimp Xiphopenaeus kroyeri (Heller, 1862). The fishes of the Sciaenidae family are most commonly found in shallow waters of the continental shelf, over sandy bottoms or mud (Menezes and Figueiredo, 1980; Souza et al., 2008) and represent the most important fishery resource in estuarine and coastal waters in the world (Chao, 1986). In Brazil this family is represented by 21 genera and 54 marine species (Menezes et al., 2003).

The genus Stellifer (Oken, 1817) comprises 24 species of fish that inhabit the coastal regions of the Atlantic and Pacific along the North, Central and South American coast (Froese and Pauly, 2010). It is distributed from Colombia to southern Brazil, its species usually attaining maximum size of 200mm (Menezes and Figueiredo, 1980) and represent up to $30 \%$ of the captured species in the seabob shrimp bycath in southeastern and southern Brazil (Branco and Verani, 2006; Coelho et al., 1986). Two of these species are Stellifer rastrifer (Jordan, 1889) and Stellifer brasiliensis (Schultz, 1945), commonly known as "Cangoá".

These species occur in abundance in the studied area, as discussed by Rodrigues-Filho (2011), where the overlapping of the reproductive period was observed. In this case, the values of relative condition factor indicated that Stellifer brasiliensis more effectively leverages food resources than $S$. rastrifer. These results were attributed to different oral structures in each species (Menezes and Figueiredo, 1980), resulting in different feeding strategies (Futuyma, 1998 ) as found by Frehse (2009) studying $S$. rastrifer and $S$. brasiliensis from the Parana state and from the northern region of the Santa Catarina state.

In this context, this study aims to analyze the natural diet of $S$. rastrifer and $S$. brasiliensis attempting to answer the following questions: a) Do changes in the trophic spectra of these species occur seasonally? b) Do species share the same food resources in the study area and, if so, is this sharing associated with changes in the conditions of healthiness?

\section{Material and Methods}

Samples were collected on a seasonal basis, in the operating area of the artisanal seabob-shrimp trawl fishery in Porto Belo, SC (27 09' 12 ' S and 48 $33^{\circ}$ '43" W), from November 2009 to August 2010, in isobaths of 10, 20 and $30 \mathrm{~m}$. The main feature of this área is the peninsula of Porto Belo, which presents sandy and rocky beaches, and is mainly composed of muddy sediments which origin of the Tijucas River and bay. Two sweeps were performed with a 15 minutes duration in each isobath, using a whaling ship equipped with two trawl doors, the net with mesh size of $3.0 \mathrm{~cm}$ and $2.0 \mathrm{~cm}$ in the bagger, navigating with a speed of approximately two knots (Branco et al., 2005). The specimens collected from the two trawls were packed in plastic bags, labeled and kept in coolers with ice until arrival at the laboratory. Vouchers were deposited in the ichthyological collection of the Biology Laboratory of the Center for Science and Technology, Land and Sea, CTTMar - UNIVALI, Santa Catarina, Brazil.

For every specimen, the standard length $(\mathrm{cm})$ and total weight ( $g$ ) were recorded. The stomachs were removed, weighed, and classified in five categories, according to a previously established scale, indicated the repletion degree: 1 = empty stomach, 2 = quarter-full stomach, 3 = halffull stomach, $4=$ three quarters full stomach and $5=$ full stomach. They were then open under a stereomicroscope.

Looking for a more cohesive analysis of the trophic spectrum (Hahn and Delariva, 2003) and considering the small size of most items we used the methods of frequency of occurrence (FO) and volumetric points (VP), which consider the relative contribution (percentage) of each item, and the total volume of food in the stomach (Hynes, 1950; Berg, 1979).

In order to evaluate the importance of each food item in the diet of the studied species, the Kawakami and Vazzoler (1980) feeding index was applied, which combines the frequency of occurrence with the points method. Diet similarity between species was calculated by the Morisita similarity index modified by Horn (1966). The values of this ratio vary from 0 to 1 , and values above 0.6 are considered indicators of high overlap (Labropoulou and Eleftheriou, 1997).

The condition factor $(\mathrm{K})$ and relative condition factor (Kr) were estimated through the expressions $\left(\mathrm{K}=\mathrm{Wt} / \mathrm{Ls}^{\mathrm{b}}\right)$ and $(\mathrm{Kr}=\mathrm{Wt} / \mathrm{We})$, respectively, where $W t$ is the total mass, We expected weight for each fish, $L s$ is standard length and $b$ is the slope of the weight-length relationship (Vazzoler, 1996). The condition factor was estimated in each length class (range of $1 \mathrm{~cm}$ ), as done by RodriguesFilho et al. (2011), while the relative condition factor was calculated seasonally. The values for each season were compared by the Kruskal-Wallis test (Zar, 1999). The weight-length relationship $\left(\mathrm{W}=\mathrm{aLt} \mathrm{t}^{\mathrm{b}}\right)$ was calculated for grouped sexes, from the set of all the individuals collected (Vazzoler, 1996). The t-student test was used in order to determine if $\mathrm{b}=3$.

\section{Results}

Of the 450 samples analyzed, Stellifer rastrifer was represented by 208 while $S$. brasiliensis by 242 specimens. From the totality of analyzed stomachs $33.49 \%$ were empty (repletion degree 1) and 66.52\% had some content (repletion degree, 2, 3, 4 and 5) (Table 1).

The species showed a similar trophic spectrum according to the number of items found with a slight difference in diversity, having Stellifer rastrifer 20 items $\left(\mathrm{H}^{\prime}=1.95\right)$ and $S$. brasiliensis $19\left(\mathrm{H}^{\prime}=1.83\right.$ ) (Tables 2 and 3$)$. The Crustacea were the predominant food category in the diet of $S$. rastrifer and $S$. brasiliensis with frequency of occurrence of $83.72 \%$ and $71.32 \%$ respectively, while occupying a relative volume of $78.88 \%$ and $78.81 \%$. The shrimp Acetes americanus (Ortmann, 1893) was the most 
Table 1. Repletion degree of stomachs analyzed of Stellifer rastrifer ( $\mathrm{Sr}$ ) and Stellifer brasiliensis (Sb) in each season, for specimens collected in Porto Belo, SC (2009/2010).

\begin{tabular}{ccccccccc}
\hline Repletion & \multicolumn{2}{c}{ Spring } & \multicolumn{2}{c}{ Summer } & \multicolumn{2}{c}{ Autumm } & \multicolumn{2}{c}{ Winter } \\
\cline { 2 - 9 } Degree & Sr & Sb & Sr & Sb & Sr & Sb & Sr & Sb \\
\hline 1 & 14 & 23 & 2 & 20 & 43 & 27 & 10 & 21 \\
2 & 28 & 28 & 6 & 36 & 45 & 23 & 7 & 14 \\
3 & 11 & 7 & 5 & 12 & 6 & 8 & 7 & 3 \\
4 & 0 & 1 & 4 & 6 & 2 & 3 & 5 & 1 \\
5 & 3 & 4 & 4 & 3 & 5 & 0 & 1 & 2 \\
Total & 56 & 63 & 21 & 77 & 101 & 61 & 30 & 41 \\
\hline
\end{tabular}

Table 2. Frequency of occurrence (\%), relative volume (\%) and feeding index by season, during the study period for each food item consumed by Stellifer rastrifer.

\begin{tabular}{|c|c|c|c|c|c|c|c|c|c|c|c|c|}
\hline \multirow{2}{*}{$\begin{array}{c}\text { Method } \\
\text { Item }\end{array}$} & \multicolumn{4}{|c|}{$\begin{array}{c}\text { Frequency of Ocurrence } \\
(\%)\end{array}$} & \multicolumn{4}{|c|}{$\begin{array}{c}\text { Relative Volume } \\
(\%)\end{array}$} & \multicolumn{4}{|c|}{ Feeding Index } \\
\hline & $\mathrm{Sp}$ & Su & Au & Wi & Sp & Su & Au & Wi & Sp & Su & $\mathbf{A u}$ & Wi \\
\hline \multicolumn{13}{|l|}{ Crustacea } \\
\hline \multicolumn{13}{|l|}{ Malacostraca } \\
\hline Decapoda un. & 17.50 & & 13.64 & & 16.82 & & 15.85 & & 0.089 & & 0.147 & \\
\hline Xiphopenaeus kroyeri & & & 2.27 & & & & 0.33 & & & & 0.001 & \\
\hline Acetes americanus & 47.50 & 7.41 & 25.00 & 94.44 & 56.78 & 6.15 & 33.48 & 93.32 & 0.815 & 0.021 & 0.571 & 0.996 \\
\hline Portunidae & & 3.70 & & & & 1.54 & & & & 0.003 & & \\
\hline Xanthidae & & 3.70 & 2.27 & & & 4.62 & 2.77 & & & 0.008 & 0.002 & \\
\hline \multicolumn{13}{|l|}{ Anomura } \\
\hline Paguroidea & & 11.11 & & & & 10.77 & & & & 0.055 & & \\
\hline Megalopa & & & 2.27 & & & & 1.11 & & & & 0.076 & \\
\hline Ovas Crustacea & & & 15.91 & & & & 6.98 & & & & 0.018 & \\
\hline Isopoda & & & 2.27 & & & & 0.55 & & & & 0.001 & \\
\hline Amphipoda & & 3.70 & 2.27 & & & 3.08 & 1.11 & & & 0.005 & 0.002 & \\
\hline Gammaridae & & 37.04 & 2.27 & & & 43.08 & 0.89 & & & 0.729 & 0.001 & \\
\hline Caprellidae & & & 2.27 & & & & 0.22 & & & & $<0.001$ & \\
\hline \multicolumn{13}{|l|}{ Maxillopoda } \\
\hline \multicolumn{13}{|l|}{ Copepoda } \\
\hline Calanoidea & 22.50 & & & & 10.83 & & 0 & & 0.074 & & & \\
\hline Cyclopoidea & 5.00 & & 11.36 & & 5.05 & & 1.77 & & 0.008 & & 0.014 & \\
\hline \multicolumn{13}{|l|}{ Echinodermata } \\
\hline Ophiuroidea & & & 2.27 & & & & 2.22 & & & & 0.003 & \\
\hline \multicolumn{13}{|l|}{ Annelida } \\
\hline Polychaeta & & 7.41 & 2.27 & & & 4.62 & 9.98 & & & 0.016 & 0.015 & \\
\hline Osteichthyes & 5.00 & 14.81 & 11.36 & 5.56 & 9.46 & 18.46 & 20.51 & 6.68 & 0.014 & 0.125 & 0.159 & 0.004 \\
\hline Scale & 2.50 & 11.11 & 2.27 & & 1.05 & 7.69 & 2.22 & & 0.001 & 0.039 & 0.003 & \\
\hline Total & 100 & 100 & 100 & 100 & 100 & 100 & 100 & 100 & 1 & 1 & 1 & 1 \\
\hline
\end{tabular}

$\mathrm{Sp}=$ Spring, $\mathrm{Su}=$ summer, $\mathrm{Au}=$ autumn and $\mathrm{Wi}=$ winter. $\mathrm{N}=99$.

frequent crustacean in stomachs of both studied species however it was consumed in different rates during each season, being most consumed by $S$. rastrifer during the winter, representing $94.44 \%$ of occurrence while it was most consumed during the summer by $S$. brasiliensis, with $44.44 \%$ of occurrence.

Osteichthyes (bony fish identified remains) was the second most frequent class, occurring in $13.17 \%$ of Stellifer rastrifer stomachs, in greater abundance during the summer (25.93\%), and occurring in $13.23 \%$ of $S$. brasiliensis stomachs, peaking in the fall (17.39\%).
The volume occupied by this category was $16.60 \%$ in S. rastrifer and $10.19 \%$ in $S$. brasiliensis. Osteichthyes and Acetes americanus were the only items present in all samples, in addition to dissolved organic matter.

Polychaetes were identified in stomach contents of Stellifer rastrifer captured during summer and autumm, being more abundant in the summer $(7.41 \%)$, but for S. brasiliensis polychaetes were present is stomachs of fish captured during the spring, summer and autumn, being more abundant in autumn $(21.74 \%)$. Polychaetes of the Nereididae family, were identified only in S. brasiliensis 
Table 3. Frequency of occurrence (\%), relative volume (\%) and feeding index by season, during the study period for each food item consumed by Stellifer brasiliensis.

\begin{tabular}{|c|c|c|c|c|c|c|c|c|c|c|c|c|}
\hline \multirow{2}{*}{$\begin{array}{c}\text { Method } \\
\text { Item } \\
\end{array}$} & \multicolumn{4}{|c|}{$\begin{array}{c}\text { Frequency of Ocurrence } \\
(\%)\end{array}$} & \multicolumn{4}{|c|}{$\begin{array}{c}\text { Relative Volume } \\
(\%)\end{array}$} & \multicolumn{4}{|c|}{ Feeding Index } \\
\hline & Sp & Su & Au & Wi & Sp & Su & Au & Wi & Sp & Su & $\mathbf{A u}$ & Wi \\
\hline \multicolumn{13}{|l|}{ Crustacea } \\
\hline \multicolumn{13}{|l|}{ Malacostraca } \\
\hline Decapoda unidentified & 24.39 & 20.63 & 26.09 & & 16.06 & 19.31 & 27.53 & & 0.197 & 0.142 & 0.404 & \\
\hline Pleoticus muelleri & & & & 11.11 & & & & 21.74 & & & & 0.126 \\
\hline Litopenaeus schmitti & & & & 11.11 & & & & 26.40 & & & & 0.153 \\
\hline Xiphopenaeus kroyeri & & & 4.35 & & & & 1.404 & & & & 0.003 & \\
\hline Acetes americanus & 31.71 & 44.44 & 17.39 & 33.33 & 40.14 & 49.93 & 14.33 & 30.12 & 0.641 & 0.788 & 0.140 & 0.523 \\
\hline Pinnotheridae & & & 8.70 & & & & 23.88 & & & & 0.117 & \\
\hline Pinnixa sp. & 4.88 & 7.94 & & & 10.39 & 10.81 & & & 0.026 & 0.030 & & \\
\hline \multicolumn{13}{|l|}{ Portunidae } \\
\hline Callinectes sp. & & & & 22.22 & & & & 12.42 & & & & 0.144 \\
\hline Amphipoda & 2.44 & & & 11.11 & 2.36 & & & 3.11 & 0.003 & & & 0.018 \\
\hline Gammaridae & & 4.76 & & & & 3.24 & & & & 0.005 & & \\
\hline Caprellidae & 2.44 & & & & 1.77 & & & & 0.002 & & & \\
\hline \multicolumn{13}{|l|}{ Maxillopoda } \\
\hline \multicolumn{13}{|l|}{ Copepoda } \\
\hline Calanoidea & 2.44 & & 4.35 & & 0.59 & & 2.25 & & $<0.001$ & & 0.006 & \\
\hline \multicolumn{13}{|l|}{ Annelida } \\
\hline Polychaeta & 9.76 & 3.17 & 21.74 & & 7.08 & 2.16 & 24.16 & & 0.035 & 0.002 & 0.296 & \\
\hline Nereidae & & 3.17 & & & & 2.88 & & & & 0.003 & & \\
\hline Bivalvia & 7.32 & 4.76 & & & 6.26 & 2.74 & & & 0.023 & 0.005 & & \\
\hline Osteichthyes & 9.76 & 7.94 & 13.04 & 11.11 & 13.93 & 8.07 & 3.65 & 6.21 & 0.068 & 0.023 & 0.027 & 0.036 \\
\hline Scale & 4.88 & 3.17 & 4.35 & & 1.42 & 0.86 & 2.81 & & 0.003 & $<0.001$ & 0.007 & \\
\hline Total & 100 & 100 & 100 & 100 & 100 & 100 & 100 & 100 & 1 & 1 & 1 & 1 \\
\hline
\end{tabular}

$\mathrm{Sp}=$ Spring, $\mathrm{Su}=$ summer, $\mathrm{Au}=$ autumn and $\mathrm{Wi}=$ winter. $\mathrm{N}=117$.

stomachs during the summer. Bivalves were found in six stomachs of S. brasiliensis during the spring (7.32\%) and summer $(4.76 \%)$. Stomachs of $S$. rastrifer did not contain any bivalves, however in the stomach of those captured in the fall, ophiuroids were present (2.77\%) (Tables 2 and 3).

Amongst the Crustacea, Isopoda, Xiphopenaeus kroyeri, caprellids and crustacean larvae (Megalopa) and eggs were food items present only during the fall in the stomachs of Stellifer rastrifer, while Portunidae crabs and hermit crabs (Paguraoidea) were present during the summer and Calanoid copepods during the spring. All other items occurred in two or more seasons. Xiphopenaeus kroyeri was also found in the stomachs of $S$. brasiliensis during the fall, while the red shrimp, Pleoticus muelleri (Bate, 1888), and white shrimp, Litopenaeus schmitti (Burkenroad, 1936), were found only during the winter, as well as crabs of the genus Callinectes. The Gammaridae amphipods were identified in stomachs of specimens collected in the summer, while representatives of the Caprellidae family were found in the spring.

The unidentified particulate organic matter as well as sand were disregarded in calculation of the Feeding Index (IAi), however it had a high frequency of occurrence and occupied significant volume in the stomachs of Stellifer rastrifer (28.27\% in total volume) and S. brasiliensis
(36.63\% in total volume). The food item with the highest value of IAi was Acetes americanus, with a value of 0.996 in winter and 0.815 in spring for $S$. rastrifer. For S. brasiliensis the values of IAI for this item were 0.788 in summer and 0.641 in spring. For other items the value was much lower (Figure 1).

In general, the overlapping in the diet of the species was high, with a value of 0.97 (Morisita-Horn index), however when analyzing the overlap in each season it was found that it occurred only during spring (0.95) and winter $(0.79)$ whereas in summer and autumn the overlap was less that $50 \%$ (0.04 and 0.45 respectively).

The mean values of the relative condition factor (Figure 2) in each species, when compared by the Kruskal-Wallis test indicated no significant differences between them, with mean values of approximately 1 in all seasons for Stellifer rastrifer while $S$. brasiliens had the same pattern except in the autumn when the mean relative condition factor was 0.67 . The weight-length curves of both species were grouped graphical representation as they showed the same weight-length patterns (Figure 3), where for the majority of individuals the length range was small, and for both species the t-student test indicated significant differences from the values of $\mathrm{b}$ and 3 ( $S$. rastrifer: $\mathrm{t}=$ 4.061, g.1. $=302 \mathrm{p}<0.001 ;$ S. brasiliensis: $\mathrm{t}=2.109$, g.1.= 

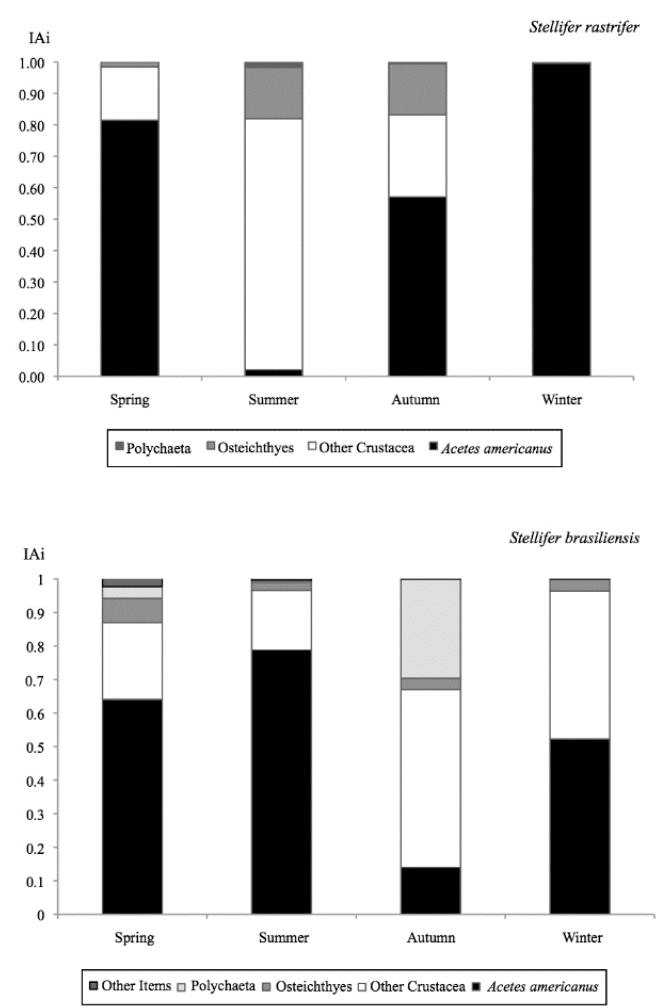

Figure 1. Kawakami and Vazzoler (1980) feeding index (IAi) for the main food items consumed by Stellifer rastrifer and $S$. brasiliensis collected in spring, summer, autumn and winter (2009/2010) in Porto Bello, Santa Catarina.

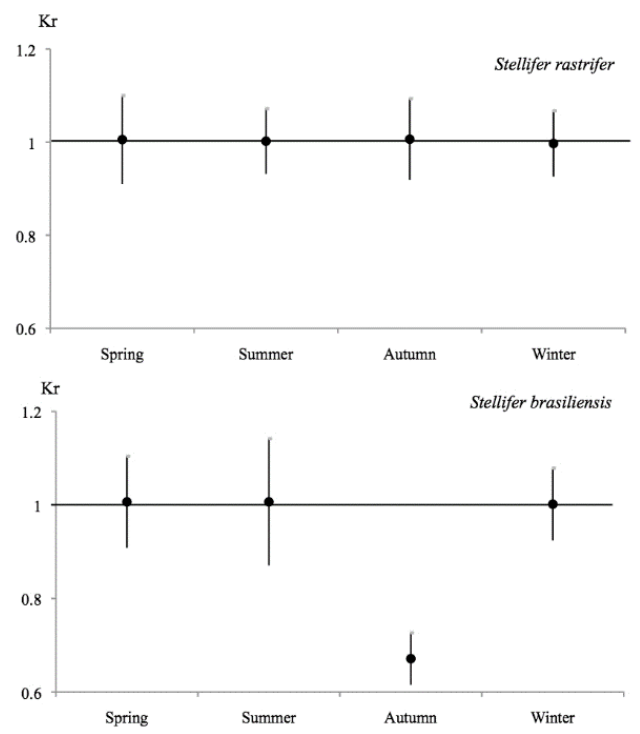

Figure 2. Relative condition factor $(\mathrm{Kr})$ of Stellifer brasiliensis and $S$. rastrifer for specimens collected in spring, summer, autumn and winter (2009/2010) in Porto Belo, Santa Catarina.

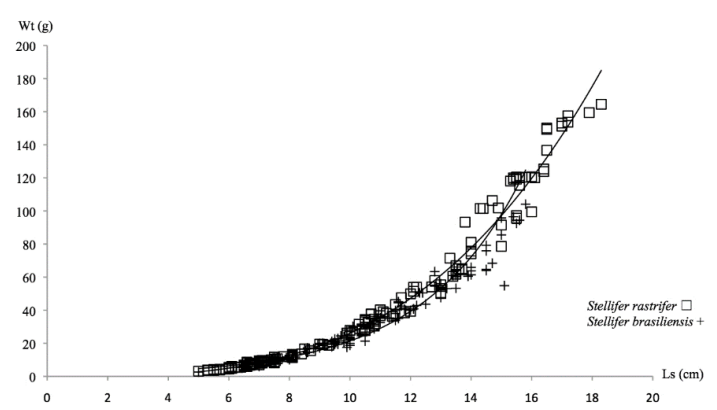

Figure 3. Weight-length curve for Stellifer rastrifer $(\mathrm{Wt}=$ $0.0151 \mathrm{Ls}^{3,2379}$ ) and S. brasiliensis $\left(\mathrm{Wt}=0.0198 \mathrm{Ls}^{3.0798}\right)$ and for specimens collected in spring, summer, autumn and winter (2009/2010) in Porto Belo, Santa Catarina.

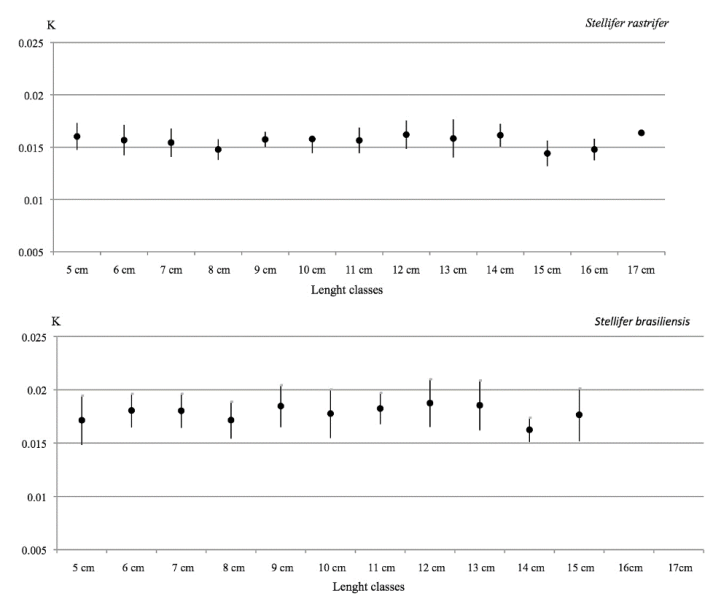

Figure 4. Condition factor $(\mathrm{K})$ by length classes $(\mathrm{cm})$ of Stellifer rastrifer and $S$. brasiliensis for all specimens collected in Porto Belo, SC (2009/2010).

$328 \mathrm{p}<0.001)$. Grouping all the collected specimens of each species, the condition factor was calculated for each length class, being a relative constant in all length classes, ranging from 0.016 to 0.014 in $S$. rastrifer and 0.018 to 0.016 in $S$. brasiliensis (Figure 4). The lowest K values for $S$. rastrifer occurred in $8 \mathrm{~cm}$ and again in $14 \mathrm{~cm}$, while in $S$. brasiliensis the same rise and fall pattern is seen in the $8 \mathrm{~cm}, 10 \mathrm{~cm}$ and again in $14 \mathrm{~cm}$.

\section{Discussion}

The diet of Stellifer brasiliensis and S. rastrifer in Porto Belo has a similar pattern to what is described in the literature (Chaves and Vendel, 1998; Frehse, 2009; Magalhães, 1993; Menezes and Figueiredo, 1980 Micheletti and Uieda, 1996; Pombo, 2010; Rodrigues and Meira, 1988), consisting of a few dominant items, most of them decapods. However a temporal analysis of diet showed seasonal variations with the appearance of a few items in some seasons, disappearing in others.

The predominant frequency of occurrence of the Sergestidae from the genus Acetes is related to the fact that they occupy the epipelagic or the mesopelagic zones 
(Simões et al., 2012), being widely consumed also by the seabob-shrimp Xiphopenaeus kroyeri (Branco 2005). Xiao and Greenwood (1993) studying the biology of Acetes, observed a clustering behavior in various spatial and temporal scales. Such behavior appears to be linked to pre-spawning activities such as mating and egg production, but also is closely associated with low temperatures present throughout the year in the sampled area due to the Falklands Current, from the Antarctic region (Gordon, 1989; Olson et al., 1988), fact that may contribute to the predominance of this food item in stomachs of fishes of the genus Stellifer. In the present study, Acetes americanus was the main food item for $S$. rastrifer in the winter, whereas in the summer it was the least consumed, however, Acetes was most consumed by $S$. brasiliensis in the summer, indicating that these congener species occupy the same area probably duo to resource partitioning. Acetes was also the predominant food item for $S$. rastrifer and S. brasiliensis collected in Santos (Rodrigues and Meira, 1988) and Ubatuba (Magalhães, 1993) São Paulo state.

The preferential intake of crustaceans has been found by other authors who have studied the genus Stellifer (Höfling et al., 1997; Magalhães, 1993; Menezes and Figueiredo, 1980; Micheletti and Uieda, 1996; Rodrigues and Meira, 1988). Despite this preference, and being the most abundant fish amongst the bycatch, Xiphopenaeus kroyeri does not appear to be an important food item in the diet for species of the genus Stellifer. In this study $X$. kroyeri appears only during the autumn in one stomach of each studied species, however some unidentified decapods may be the seabob shrimp. A similar result was found by Rodrigues and Meira (1988), with the presence of the seabob shrimp in only 22 of the 77 analyzed stomachs of $S$. rastrifer and 2 of the 36 analyzed stomachs of $S$. basiliensis. It is known that penaeid shrimps are benthic and burry themselves in the sediment (Castilho et al., 2008; Simões et al., 2012), and therefore are available in a smaller scale for benthopelagic consumers, such as $S$. rastrifer and S. brasiliensis (Wakabara et al., 1993). Even if juveniles of $X$. kroyeri, are available in the pelagic zones for these fishes, they may be choosing to consume shrimp from the genus Acetes not only for their abundance in the studied environment, but for their short and blunt rostrum, that are of easier consumption than the sea-bob's rostrum with five teeth near the base and slightly curved upwards.

Micheletti and Uieda (1996) described and compared the diet of the ten most abundant sciaenids in Flamengo Bay, Ubatuba, and crustaceans and fish were the main food items consumed by Stellifer brasiliensis and S. rastrifer. A similar result was found by Höfling et al. (1997) studying the diet of sciaenids in the estuarine complex of Cananeia, with the predominant intake of crustaceans, yet Chaves and Vendel (1998), dealing specifically with the diet of $S$. rastrifer in a mangrove area in Guaratuba, Parana state, identified polychaetes and "shrimps" (non-brachyuran decapods) as major food items with a marked difference in composition at each season. The predominance of polychaetes in this case may be due to the sampled location, as usually estuary sediment is rich in organic matter, which favors for the development of this type of organisms. Thus, differences in food items may be a consequence of the characteristics of each study area.

According to Lucena et al. (2000), without seasonal variation in diet, both intra-and inter-specific competition will be favored, which may end up causing negative impacts in one or more species. However Colwell and Futuyma (1971) assert that diets with high similarity do not necessarily indicate competition as food resources can be abundant and shared between different species resulting in dietary overlap.

Regarding the analysis of dietary overlap between the two species of fish in question, although the composition of their diets has been shown to be similar in this and other studies, authors do not usually attest strong dietary overlap between them, although the composition of the diets has shown to be recurrently similar. Magalhães (1993) observed a significant difference between the diets of Stellifer rastrifer and S. brasiliensis while Frehse (2009) found no evidence of strong dietary overlap between them. Micheletti and Uieda (1996) found less than 40\% similarity and yet Pombo (2010) found no similarity percentage lower than $60 \%$.

A more detailed analysis on overlap shows differences in the proportions of ingested items. According to Zaret and Rand (1971), even when these differences are small there is no reason to suppose that similarities in diet indicate direct competition when other factors, such as spatiotemporal environmental differences are not analyzed simultaneously. According to Hynes (1950), when a food item is exploited by two or more fish species, their relative significance to each of these species is generally different, as observed during the summer and autumn in Porto Belo studied area. Although the most important items in the diet of these species are the same, the intake of each alternates in time, suggesting a difference in predation pressure, which leads to less direct competition in a given time. The coexistence of similar species within the same ecosystem may occur owing to different resource use, as resource partitioning includes food, habitat and/or time segregation (Pianka, 1973; Schoener, 1974), and seasonal fluctuations in food resource availability have been shown to modify resource partitioning among sympatric fish species (Jepsen et al., 1997).

The distribution of the allometric condition factor by length classes for all captured individuals of each species shows a decline in the value of $\mathrm{K}$ in the first length classes, raising again in $9 \mathrm{~cm}$ and decreasing again in $14 \mathrm{~cm}$ for Stellifer rastrifer and $S$. brasiliensis, however the variation was so low that overall the species condition remained constant. As seasonal changes direct effect on condition factors, which have been shown to be correlated with gonad cycles, rate of feeding, etc (Le Cren, 1951), it is likely that the lower relative condition factor value found during the fall for $S$. brasiliensis is a result of the sampling of young individuals with smaller lengths.

Despite no significant differences between seasons indicated by the Kruskal-Wallis test, the value of 0.67 for the condition factor reflects a greater abundance of 
specimens with standard length ranging from 5 to $8 \mathrm{~cm}$. A similar length distribution for the congener species Stellifer stellifer was found by Almeida and Branco (2002), in Penha, a county in Santa Catarina Satate, located only a few miles from Porto Belo, when in the fall of 1997 $64.5 \%$ of the sample were represented by individuals shorter than $8 \mathrm{~cm}$. A larger number of sampled juveniles was also found by Rodrigues-Filho et al. (2011) in the same area. This can be explained by the low selectivity in bottom trawls used in shrimp fisheries (Coelho et al., 1985, 1987; Giannini and Paiva Filho, 1990, 1995), and therefore very subtle variations in the values of $\mathrm{Kr}$ for the two species throughout the year, leads us to disregard any significant seasonal variation in the feeding composition, so that these variations would not be a result of food shortages or changes of abiotic factors, but reflect the changing age structure of the population, since it is influenced by the entry of new individuals periodically, whether small or bigger (youth and adults).

Our results therefore enable us to answer the previously made questions. Very subtle changes occur seasonally in the trophic spectra for both studied species, and as they share the same food resources with the intake of each item occurring in different moments, a difference in predation pressure becomes evident, with less direct competition in a given time. This is reflected in stable values of the allometric condition factor and the relative condition factor, that in association with the weight-length relationship for both species, lets us assess that the their high nutritional condition, that may be due to abundant food items present in the studied environment, despite the constant exploitation by the seabob-shrimp fisheries.

\section{Acknowledgements}

The authors would like to thank Federal University of São Carlos (UFSCar) Program in Ecology and Natural Resources and the UNIVALI Office of Graduate Research, Extension and Culture for their support; CNPq for research project grants and for Lia Sabinson's graduate scholarship.

\section{References}

ALMEIDA, LR. and BRANCO, JO., 2002. Aspectos biológicos de Stellifer stellifer (Bloch) na pesca artesanal do camarão setebarbas, Armação do Itapocoroy, Penha, Santa Catarina, Brasil. Revista Brasileira de Zoologia, vol. 19, no. 2, p. 601-610. http:// dx.doi.org/10.1590/S0101-81752002000200016.

BERG, J., 1979. Discussion of methods of investigating the food fishes with reference to a preliminary study of prey of Gobiusculus flavescens (Gobiidae). Marine Biology, vol. 50, no. 3, p. 263-273. http://dx.doi.org/10.1007/BF00394208.

BRANCO, JO., 2005. Biologia e pesca do camarão sete-barbas Xiphopenaeus kroyeri (Heller) (Crustacea, Penaeidae), na Armação do Itapocoroy, Penha, Santa Catarina, Brasil. Revista Brasilieira de Ornitologia, vol. 22, p. 1050-1062.

BRANCO, JO., and VERANI, JR., 2006. Pesca do camarão setebarbas e sua fauna acompanhante, na Armação do Itapocoroy, Penha, SC. In BRANCO, JO.; MARENZI, AWC. (Eds.). Bases ecológicas para um desenvolvimento sustentável: estudos de caso em Penha, SC. Itajaí: Editora da UNIVALI. p. 153-170.

BRANCO, JO., FRACASSO, HAA., MACHADO, IF., BOVENDORP, MS. and VERANI, JR., 2005. Dieta de Sula leucogaster Boddaert (Sulidae, Aves), nas Ilhas Moleques do Sul, Florianópolis, Santa Catarina, Brasil. Revista Brasileira de Zoologia, vol. 22, no. 4, p. 1044-1049. http://dx.doi.org/10.1590/ S0101-81752005000400033.

CASTILHO, AL., PIE, MR., FRANSOZO, A., PINHEIRO, AP., and COSTA, RC., 2008. The relationship between environmental variation and species abundance in shrimp community (Crustacea: Decapoda: Penaeoidea) in south-eastern Brazil. Journal of the Marine Biological Association of the UK, vol. 88, no. 1, p. 119123. http://dx.doi.org/10.1017/S0025315408000313.

CHAO, LN., 1986. A synopsis on zoogeography of the Sciaenidae. In UYENO, T., ARAI, R., TANIUCHI, T. and MATSUURA, K. (Eds.). Indo - Pacific fish biology: Proceedings of the Second International Conference on Indo-Pacific Fishes. Tokyo: Ichthyological Society of Japan. p. 570-589.

CHAVES, PDTC., and VENDEL, AL., 1998. Feeding Habits of Stellifer rastrifer (Perciformes, Sciaenidae) at Guaratuba Mangrove, Parana, Brazil. Brazilian Archives of Biology and Technology, vol. 41, no. 4, p. 423-428.

COELHO, JAP., LOPES, RG., RODRIGUES ES. and PUZZI A., 1985. Relação peso- comprimento e tamanho de inicio de primeira maturação gonadal para o Scianidae Stellifer reastrifer (JORDAN, 1889) no litoral do estado de São Paulo. Boletim do Istituto de Pesca, vol. 12, p. 99-107.

COELHO, JAP., LOPES, RG., SEVERINO-RODRIGUES, E. and PUZZI, A., 1987. Aspectos biológicos e pesqueiros do Sciaenidae Stellifer brasiliensis (Schultz, 1945), presente na pesca artesanal dirigida ao camarão sete-barbas (São Paulo, Brasil). Boletim do Istituto de Pesca, vol. 14, p. 1-10.

COELHO, JAP., PUZZI, A., LOPES, RG., RODRIGUES, ES., and PRETO JUNIOR, O., 1986. Análise da rejeição de peixes na pesca artesanal dirigida ao camarão sete-barbas. Boletim do Istituto de Pesca, vol. 13, p. 51-61.

COLWELL, RK. and FUTUYMA, DJ., 1971. On the measurement of niche breadth and overlap. Ecology, vol. 52, no. 4, p. 567-576. http://dx.doi.org/10.2307/1934144.

FREHSE, FA., 2009. Estrutura populacional e dieta de Stellifer rastrifer (Jordan, 1889) e Stellifer brasiliensis (Schultz, 1945) (Sciaenidae, Perciformes), nos periodos diurno e noturno, em quatro áreas da plataforma sul do Estado do Paraná e norte do Estado de Santa Catarina. p. 1-66. Curitiba: Universidade Federal do Paraná. Ph.D. Dissertation.

FROESE, R. and PAULY, D. (Eds.), 2010. FishBase. Version $(01 / 2010)$. Available from: <www.fishbase.org $>$. Access in: date 10 Oct. 2012.

FUTUYMA, DJ., 1998. Evolutionary Biology. 3nd ed. Sunderland: Sinauer Associates. 646 p.

GIANNINI, R., and PAIVA FILHO, AM., 1990. Aspectos bioecológicos de Stellifer rastrifer (Perciformes:Sciaenidae) na Baía de Santos, SP. Boletim do Instituto Oceanográfico, vol. 38 , p. 57-67.

GIANNINI, R., and PAIVA FILHO, AM., 1995. Distribuição temporal, espacial e bioecologia do Cangoá, Stellifer brasiliensis (Teleostei:Sciaenidae), na Baía de Santos, São Paulo, Brasil. Arquivos de Ciências do Mar, vol. 29, p. 5-15.

GORDON, AL., 1989. Brazil-Malvinas Confluence - 1984. Deep-Sea Research, vol. 36, no. 3, p. 359-384. http://dx.doi. org/10.1016/0198-0149(89)90042-3. 
HAHN, NS., and DELARIVA, RL., 2003. Métodos para avaliação da alimentação de peixes: o que estamos usando? Interciencia, vol. 28 , p. 100-104.

HÖFLING, JC., FERREIRA, LI., RIBEIRO-NETO, FB., PAIVA-FILHO, AM., MARTINHO, LR. and DONZELI, VP., 1997. Alimentação de peixes da família Sciaenidae do complexo estuarino-lagunar de Cananéia, SP, Brasil. Bioikos, vol. 11, p. 7-21.

HORN, HS., 1966. Measurment of "overlap" in comparative ecological studies. American Naturalist, vol. 100, no. 914, p. 419-424. http://dx.doi.org/10.1086/282436.

HYNES, HBN., 1950. The food of fresh-water sticklebacks (Gasterosteus aculeatus and Pygosteus pungitius), with a review of methods used in studies os the food of fishes. Journal of Animal Ecology, vol. 19, no. 1, p. 36-51. http://dx.doi.org/10.2307/1570.

JEPSEN, DB., WINEMILLER, KO. and TAPHORN, DC., 1997. Temporal patterns of resource partitioning among Cichla species in a Venezuelan blackwater river. Journal of Fish Biology, vol. 51, p. $1085-1108$

KAWAKAMI, E. and VAZZOLER, AEAM., 1980. Método gráfico e estimativa de indice alimentar aplicado no estudo de alimentação de peixes. Boletim do Instituto Oceanográfico, vol. 29, no. 2, p. 205-207. http://dx.doi.org/10.1590/S0373-55241980000200043.

KEUNECKE, KA., VIANNA, M., FONSECA, DB., and D'INCAO, F., 2007. The pink-shrimp trawling bycatch in the northern coast of São Paulo, Brazil, with emphasis on crustaceans. Nauplius, vol. 15 , p. 49-55.

LABROPOULOU, M. and ELEFTHERIOU, A., 1997. The foraging ecology of two pairs of congeneric demersal fish species: importance of morphological characteristics in prey selection. Journal of Fish Biology, vol. 50, no. 2, p. 324-340. http://dx.doi. org/10.1111/j.1095-8649.1997.tb01361.x.

LE CREN, ED., 1951. The Length-Weight Relationship and Seasonal Cycle in Gonad Weight and Condition in the Perch (Perca fluviatilis). British Ecological Society, vol. 20, no. 2, p. 201-219.

LUCENA, FM., VASKE, T., ELLIS, JR. and O'BRIEN, CM., 2000. Seasonal variation in the diets of bluefish, Pomatomus saltatrix (Pomatomidae) and striped weakfish, Cynoscion guatucupa (Sciaenidae) in southern Brazil: implications of food partitioning. Environmental Biology of Fishes, vol. 57, no. 4, p. 423-434. http://dx.doi.org/10.1023/A:1007604424423.

MAGALHÃES, SBC., 1993. Reprodução e alimentação das espécies do gênero Stellifer (Perciformes, Sciaenidae) na região de Ubatuba - Litoral Norte do Estado de São Paulo. Rio Claro Universidade Estadual Paulista. Dissertation.

MATHEWS, CP., and SAMUEL, M., 1991. Growth, mortality and lenght-weight parameters for some kuwaiti fish and shrimp. Fishbyte, vol. 9, p. 30-33.

MENEZES, NA. and FIGUEIREDO, JL., 1980. Manual de Peixes Marinhos do Sudeste do Brasil. IV. Teleostei (3). São Paulo: Museu de Zoologia, Universidade de São Paulo. 96 p.

MENEZES, NA., BUCKUP, PA., FIGUEIREDO, JL. and MOURA, RL., 2003. Catálogo das espécies de peixes marinhos do Brasil. São Paulo: Museu de Zoologia, Universidade de São Paulo. 160 p.

MICHELETTI, CV., and UIEDA, VS., 1996. Food resources among Sciaenid Fishes (Perciformes, Sciaenidae) of the Flamengo Bay, Ubatuba, southeastern Brazil. Arquivos de Biologia e Tecnologia, vol. 39, p. 639-649.

OLSON, DB., PODESTÁ, GP., EVANS, RH. and BROWN, OB., 1988. Temporal variations in the separation of Brazil and Malvinas Currents. Deep-Sea Research, vol. 35, no. 12, p. 1971-1990.
PIANKA, ER., 1973. The structure of lizard communities. Annual Reviews of Ecologycal Systems, vol. 21, p. 213-220.

POMBO, M.,2010. Biologia populacional e dieta de Stellifer rastrifer (Jordan, 1889), S. stellifer (Bloch, 1790) e S. brasiliensis (Schultz, 1945) (Perciformes, Sciaenidae) na Enseada de Caraguatatuba (SP). São Paulo, Universidade de São Paulo Instituto Oceanográfico Dissertation.

RODRIGUES, ES., and MEIRA, PTF., 1988. Dieta aliementar de peixes presentes na pesca dirigida ao camarão sete-barbas (Xiphopenaeus kroyeri) na baía de Santos e praia do Perequê, estado de São Paulor, Brasil. Boletim do Instituto de Pesca, vol. 15 , p. $135-146$.

RODRIGUES-FILHO, JL., VERANI, JR., PERET, AC., SABINSON, LM. and BRANCO, JO., 2011. The influence of population structure and reproductive aspects of the genus Stellifer (Oken, 1817) on the abundance of species on the southern Brazilian coast. Brazilian Journal of Biology, vol. 71, no. 4, p. 1-12. http:// dx.doi.org/10.1590/S1519-69842011000500019.

SCHOENER, TW., 1974. Resource partitioning in ecological communities. Science, vol. 185, no. 4145, p. 27-39. http://dx.doi. org/10.1126/science.185.4145.27. PMid:17779277

SHERIDAN, PR., BROWDER, JA. and POWERS, JE., 1984. Ecological interaction between penaeid shrimp and bottomfish assemblages. In GULLANDAND, JA., ROGHSCHILD, BJ. (Eds.). Penaeid shrimp - their biology and management. Selected papers presented at the workshop on the scientific basis for the management of penaeid shrimp, held at Key West Florida, November 1981. Farnham: Fishing News Books. p. 235-250.

SIMÕES, SM., CASTILHO, AL., FRANSOZO, A., NEGREIROSFRANSOZO, ML., and COSTA, RC., 2012. Distribution related to temperature and salinity of the shrimps Acetes americanus and Peisos petrunkevitchi (Crustacea: Sergestoidea) in the southeastern Brazilian littoral zone. Journal of the Marine Biological Association of the United Kingdom, vol. 93, no. 3, p. 753-759. http://dx.doi.org/10.1017/S0025315412000902.

SOUZA, UP., COSTA, RC., MARTINS, IA. and FRANSOZO, A., 2008. Associações entre as biomassas de peixes Sciaenidae (Teleostei: Perciformes) e de camarões Penaeoidea (Decapoda: Dendrobranchiata) no litoral norte do Estado de São Paulo. Biota Neotropica, vol. 8, no. 1, p. 83-93. http://dx.doi.org/10.1590/ S1676-06032008000100011.

VAZZOLER, AEAM., 1962. Sobre a primeira maturação sexual e destruição de peixes imaturos. Boletim do Instituto Oceanográfico, vol. 12, p. 5-38.

VAZZOLER, AEAM., 1996. Biologia da reprodução de peixes teleósteos: teoria e prática. Maringá: EDUEM/SBI. 169 p.

WAKABARA, Y., TARARAM, AS. and FLYNN, MN., 1993. Importance of the macrofauna for the feeding of young fish species from Infralittoral of Arrozal, Cananéia lagoon estuarine region $\left(25^{\circ} 02^{\prime} \mathrm{S}-47^{\circ} 56^{\prime} \mathrm{W}\right)$, Brazil. Boletim do Instituto Oceanográfico, vol. 41, no. 1-2, p. 39-52.

XIAO, Y. and GREENWOOD, JG., 1993. The biology of Acetes (Crustacea, Sergestidae). Oceanography and Marine Biology - an Annual Review, vol. 31, p. 259-444.

ZAR, JH., 1999. Bioestatistical analysis. 4th ed. New Jersey: Prentice Hall.

ZARET, TM. and RAND, AS., 1971. Competition in tropical stream fishes: support for the competitive exclusion principle. Ecology, vol. 52, no. 2, p. 336-342. http://dx.doi.org/10.2307/1934593. 